Article

\title{
The Influence of Household Heterogeneity Factors on the Green Travel Behavior of Urban Residents in the East China Region
}

\author{
Ranran Yang ${ }^{1, *,+}$, Ruyin Long ${ }^{2,+}$, Yu Bai ${ }^{1, \dagger}$ and Lanlan $\mathrm{Li}^{1,+}$ \\ 1 School of Management, Hefei University of Technology, Hefei 230009, China; wyby1984@hfut.edu.cn (Y.B.), \\ 111428@hfut.edu.cn (L.L.) \\ 2 School of Management, China University of Mining and Technology, Xuzhou 221116, China; \\ longruyin@cumt.edu.cn \\ * Correspondence: yangranran@hfut.edu.cn; Tel.: +86-0551-6291-9155 \\ $\dagger$ These authors contributed equally to this work.
}

Academic Editors: Yongrok Choi, Malin Song and Seunghwan Myeong

Received: 30 November 2016; Accepted: 3 February 2017; Published: 10 February 2017

\begin{abstract}
A questionnaire survey was conducted with 1475 urban residents in the east region of China to explore the impact of household heterogeneity factors on the green travel behavior of urban residents. The green travel behavior was divided into practice-based and promotion-based green travel behavior, and the results showed that variables including gender, age, educational background, household monthly income, amount of cars, professional status, positional tiers and housing ownership were correlated with both of the two types of green travel behavior significantly. Variables that included having elderly family members or not, having children or not, and position level were only correlated with practice-based green travel behavior significantly. Moreover, the study found that the variables female, elderly and young, highly educated, low-income, low professional status, low positional tiers, low positional status, house-renting, not having elderly family members or children and having fewer cars had a significantly positive impact on green travel behavior.
\end{abstract}

Keywords: household heterogeneity factors; urban residents; green travel behavior

\section{Introduction}

With the rapid expansion of urbanization and urban mechanization, Chinese car ownership is growing in intensity and, thus, a series of problems, such as urban road traffic congestion, transport energy consumption and urban air pollution, are becoming prominent issues. Niu's investigation data in Chinese new-type urbanization report indicate that, in cities with populations above a million in China, the traffic capacities of over $80 \%$ of the road segments and $90 \%$ of the road crossings have reached their limits [1]. Moreover, traffic congestion is no longer a metropolitan phenomenon, with regions of middle and small cities having more serious congestion than the larger cities including Beijing, Shanghai, and Guangzhou [2]. At present, Chinese traffic fuel consumption accounts for one-third of the national total fuel consumption, and according to predictions, petroleum consumption for transport, which accounts for $55 \%-60 \%$ of the national total petroleum consumption, will be the largest sector by the year 2020 [3]. Of all passenger transport modes, including car, public bus, civil aviation and railway, the energy consumption of the car is the greatest and this is increasing progressively year by year [4]. Now, with a leap in car ownership, the huge amount of exhaust fumes from cars has become one of the main sources of urban air pollution. Based on the 2013 IEA (International Energy Agency) report, $\mathrm{CO}_{2}$ emissions from the transport sector account for $8.4 \%$ of total $\mathrm{CO}_{2}$ emissions from fuel combustion in China. The road transport sector accounts for $81.3 \%$ of all 
transport sectors in China, a proportion that is higher than the global average and continues to increase gradually [5]. At the same time, with the transformation of travel structure, the $\mathrm{CO}_{2}$ emissions from cars are the highest proportion of all passenger transport modes and this proportion has increased from $51 \%$ in 2000 to $82 \%$ in 2011 according to the research results of Wang and Liu [6]. On the other hand, carbon monoxide, hydrocarbon, oxynitride and solid suspended particulate matter generated by motor vehicle exhaust emission are very hazardous for human health and even life-threatening. This is because the range of motor vehicle exhaust emission is $0.3-2$ meters, similar to the range of human respiration. Motor vehicle exhaust emission directly stimulates human respiratory system, skin and eyes [7].

Based on socioeconomic development status, the State Statistics Bureau on 13 June 2011 divided the Chinese mainland into four economic areas: the eastern region, central region, northeast region, and western region. The economic development levels of different economic areas vary greatly, with the eastern region having the highest economic development level and the highest population and distribution of cities. The east China region includes 10 provinces and cities: Beijing, Tianjin, Hebei, Shanghai, Jiangsu, Zhejiang, Fujian, Shandong, Guangdong, and Hainan. The amount of private car ownerships of the 10 provinces and cities in the east China region accounts for more than $50 \%$ of the national total, and this amount has increased by about $20 \%$ annually in recent years [8]. Based on the 2015 transportation analysis report of major cities in China, on a national scale, the urban traffic congestion of east China region is the most serious, and seven of the ten most congested Chinese cities belong to the east China region [9]. Moreover, based on the Chinese PM2.5 space-time distribution diagrams published in the Chinese Journal of Nature drawn by the research group of Yale-NUIST Center on Atmospheric Environment, the east China region is the most serious region in haze, the PM2.5 index of the Beijing-Tianjin-Hebei region, especially, is staying at a high level all year round [10]. In other words, compared with other regions in China, the traffic congestion, carbon emissions and air pollution of the east China region are more serious due to the higher amount of car owners.

To solve the above problems, China is appealing to the public to implement green travel. Green travel, which could reduce the travel energy consumption and pollution, had been brought into the 13th Five Year Plan after the 12th Five Year Plan. Meanwhile, the above data indicate that there is a realistic significance to research how the government guides urban residents of the east China region into implementing green travel. Urban residents are the key subjects of the implementation of green travel; that is, the development of green travel is inseparable from the residents' participation. Recently, many scholars have paid close attention to the relationship between green travel behavior and the individual, as the subject of household consumption, but relatively few studies are focused on the impact of household heterogeneity factors on green travel behavior. Therefore, this article aims to investigate the impact of household heterogeneity factors on urban residents' green travel behavior, to provide some relevant basis and policy suggestions for the government to guide urban residents' green travel behavior to normalization.

\section{Literature Review and Research Hypothesis}

\subsection{Literature Review}

The concept of green travel came from the idea of green transport, but does not have a unified or clear definition. As a manifestation of green consumerism, green travel is a new type of travel idea from the individual realization that the environmental problem is in the context of an environmental crisis. Green travel aims to guide residents to choose travel modes which use low-energy, are energy efficient, low polluting, and balance efficiency with fairness, and are a benefit to the sound development of the city and the citizen. Therefore, as an environmental behavior, green travel behavior is a conscious effort made in order to avoid or solve environmental problems [11,12]. Thus, this article defines urban residents' green travel behavior as a conscious effort action, in the context of considering the 
harmonious development of people, society and environment; that is, to do effort consciously to reduce the energy consumption and pollution in their own or others' travel.

This article combines the characteristics of green travel to classify green travel behavior into two types: practice-based and promotion-based [13-15]. Practice-based green travel behavior is a physical daily practice, an adjustment behavior that is initiatively exercised (adjusting existing travel mode to green travel mode). In other words, practice-based green travel behavior is a direct curtailment and adjustment behavior, such as taking public transport instead of driving or taking taxi. Promotion-based green travel behavior is a lobbying operation between residents, or a behavior where residents take an active part or suggest others take part in green travel behavior relevant to an organization or activities. In other words, promotion-based green travel behavior can be viewed as an interpersonal interaction behavior, such as persuading the people around to take more public transport instead of driving or taking taxi. Practice-based green travel behavior is an immediacy behavior, whereas promotion-based green travel behavior may not be, but it can prompt the occurrence of green travel behavior to some extent.

According to the purpose of the trip, various travel behaviors can be divided broadly into two types: daily local travel and tourism travel. In view of the frequency and seriousness of environmental air pollution, only daily local travel is the focus of this article.

The majority of recent research results indicate that sociodemographic characteristics are significant contributors that impact on environmental behavior [16-18]. As a type of environmental behavior, green travel behavior is also affected significantly by sociodemographic characteristics $[19,20]$. Factors that are considered sociodemographic characteristics mainly included gender, age, graduation, income, family structure and size. For example, Golob and Hensher found that demographic characteristics have significant impact on travelers' environmental protection behavior; in other words, environment friendly travel behavior varied in demographic characteristics, and those travelers who are female, under 30 years old and over 50 years old, with high educations and incomes, and with low car ownership are more willing to participate in environment friendly travel behavior [21]. Specifically, gender was a significant influencing factor of green travel behavior. Prillwitz and Barr investigated urban residents' daily travel behavior and found that females were favoring green travel more than males [22]. Simma and Axhausen studied the commuting behavior of Australian residents, and their results showed that males wanted to own a car more than females, while females were more willing to choose walking or public transportation than males [23]. Polk's research indicated that the frequency of car use by Swedish women was significantly less than for Swedish men, and the intention to reduce car usage by Swedish women was stronger than for Swedish men [24]. Age was also considered a significant influencing factor of green travel behavior. The research results of Plaut demonstrated that those under 25 years old showed a higher propensity for non-motorized travel [25]. The study of Klineberg et al. [26] and Singh [27] showed that younger age groups gave higher attention to ecological environmental problems and a higher implementation rate of pro-environmental behavior and had a social responsibility in consuming behavior with sustainable development. However, some studies have pointed out that older age groups may pay more attention to recycling and find it easier to implement sustainable consuming behavior [28,29]. In terms of the relationship between educational background and green travel behavior, most studies showed that residents' green travel behavior was proportional to their educational background. Golob and Hensher [21] and Plaut [25] found that travelers with a college diploma and above were more willing to participate in pro-environmental travel behavior. Ma and Liao surveyed urban residents' low-carbon trip situation in $\mathrm{Xi}^{\prime}$ an, and their results showed that, if residents received suitable guidance and realistic conditions, the higher the educational background the residents possessed, the greater was the frequency of their low-carbon trips because the residents with a higher education owned a stronger ability of accepting new ideas and a sense of social responsibility [30]. Generally speaking, residents' standard energy consumption is proportional to their income and this view had been verified by most scholars [31,32]. However, the higher energy consumption level caused by a higher income did not influence residents' implementation of green 
travel behavior. Based on data from international social surveys, Franzen and Meyer verified that the attention on the environment by the individual or the nation was proportional to their income or level of affluence [33]; Prillwitz and Barr also verified this result [22]. Some studies have demonstrated that the individual's occupation has a significant impact on his or her environmental behavior [34]; for instance, Liu found that people with a higher social position were more inclined to adopt green consumption [35]. Some studies have also demonstrated that residents who own their property could significantly influence their energy consuming behavior, specifically, residents who owned their property were more inclined to invest in energy efficiency, while residents who did not own their property were more inclined to change their behavior to reduce their energy consumption [36]. Through verifying the relationship between residents' housing and their energy saving behavior on home heating and oil consumption, Painter et al. found that housing was the fourth most important variable for differentiating whether the resident is an energy-efficient person [37]. Family scale and structure directly influence energy consumption, and household energy consumption generally increases as the amount of family members increases [38]. Prillwitz and Barr investigated residents' daily travel behavior, and their results showed that $58 \%$ of families did not have children in the group that preferred green travel, and the greater the amount of children in a family, the lower the rate in which they preferred green travel [22]. At the same time, car ownership was also considered a key factor influencing green travel behavior by the majority of scholars. Through surveying the residents of 13 communities in England, Susilo et al. found that the rate of residents choosing cycling or public transport would decrease greatly if residents owned one or more private cars [39]. Plaut indicated that the more private cars residents owned, the higher the intention of residents to choose motorized travel [25], and Golob and Hensher verified that travelers with fewer private cars were more willing to participate in pro-environmental travel behavior [21].

However, a few scholars have queried the relationship between social demographic variables and environmental behavior, and believe that this relationship was not stable [40,41]. In investigating environmental protection by organization members, Marcinkowski considered age, gender, date of birth, educational status, occupation, socioeconomic status, political view point, youth residence and hometown size as social demographic variables and used these variables to predict environmental behavior. He found that the variables contributed little in predicting environmental behavior [42]. Both Scheiner's investigation of German residents' travel modes from 1976 to 2002 [43] and Hjorthol's investigation of Norwegian residents' travel modes from 1992 to 2005 [44] showed that the influence of gender on travel mode chosen fell off rapidly, in other words, there was no significant difference between males and females in the area of travel mode choice. Some studies indicate that there was no significant correlation between education and green travel behavior; however, some studies found a negative correlation; for instance, Singh found that the implementation rates of socially responsible consumer behavior of those people with a higher education were lower [27], and Böhler et al. pointed out that the group with a higher educational background were more inclined to choose motorized travel [31]. In addition, some studies demonstrate that there was no significant correlation between income and green travel behavior; however, some studies found a negative correlation; for instance, Samdahl and Robertson found that the environmental awareness of low income residents was noticeably higher than the social average level [45], and both Singh [27] and Wang [29] found that low income residents were more inclined to implement recycling consumption behavior and socially responsible consumer behavior. The majority of studies have demonstrated that there was no significant relationship between residents' occupations and their environmental behavior [46]. Overall, scholars believed that social demographic variables did not have a significant impact on green consuming behavior $[27,47]$.

In conclusion, although the existing literature on the relationship between social demographic characteristics and green travel behavior has obtained uncertain results, the definitions of specific factors and mechanisms of social demographic characteristics are not always consistent because of differences in regional cultures and social economic development. Furthermore, the existing research 
on green travel behavior focuses on Europe and the United States and other developed countries, and research that is focused on Chinese urban residents is relatively deficient, so the social demographic characteristics of urban residents' green travel behavior in the Chinese context remains to be verified.

Family is the major factor of the urban residents' life. Family structure, size, income, educational background and occupation and social status all influence the residents' travel mode, and restrain the social and economic boundaries of the travel mode choice [48,49]. Therefore, this article takes household heterogeneity factors as the research perspective, not only focusing on demographic variables, and this could describe the essential characteristics of urban residents' green travel behavior more accurately to some extent.

\subsection{Research Hypothesis}

Based on a literature review, combined with the family characteristics and travel modes and habits of Chinese urban residents, this article points out that the household heterogeneity influencing factors of urban residents' green travel behavior include gender, age, educational background, occupation, household monthly income, housing ownership, whether there are elderly members over 60 years old in the family, whether there are children under 12 years old in the family, and the amount of private cars. According to the literature and expert suggestion, the relationship between the occupation and social status should be considered; this article measures occupation by professional status, positional tiers, and positional status. Furthermore, this article adopts the information of householder to denote residents' statistical characteristics such as gender, age, educational background, and occupation. The research hypotheses discussed above are summarized in Table 1.

Table 1. Research hypothesis.

\begin{tabular}{cl}
\hline Number & \multicolumn{1}{c}{ Research Hypothesis } \\
\hline H1 & Green travel behavior is different for men and women \\
H2 & Green travel behavior is different for various age ranges \\
H3 & Green travel behavior varies depending on educational background \\
H4 & Green travel behavior varies depending on family monthly income \\
H5 & Green travel behavior varies with various positional status \\
H6 & Green travel behavior varies with various profesional status \\
H7 & Green travel behavior varies with various positional tiers \\
H8 & Green travel behavior is different for different housing types \\
H9 & Green travel behavior shows significant variations by whether there are elderly people \\
& over 60 years old in the family \\
H10 & Green travel behavior shows significant variations by whether there are children under \\
H11 & Green travel behavior varies depending on the amount of private cars \\
\hline
\end{tabular}

Note: Green travel behavior includes practice-based green travel behavior and promotion-based green travel behavior.

\section{Research Method and Data Sources}

\subsection{Research Method}

To collect the basic data, this article has adopted a questionnaire survey, a method widely used in research fields such as environmental behavior, energy usage and consuming behavior. Firstly, we designed the initial scale of this study based on existing studies, and combined with expert advice and results of interviews with representative residents. According to Chinese urban residents' usual travel and green travel, the initial scale of this article was amended for localization. Next, through small sample pre-research which was designed to find possible problems and test the validity of the scale, the initial scale was amended to the formal scale. The formal scale included three parts comprised of 20 items: statistics of household heterogeneity factors, statistics of urban residents' current travel modes, and the measurement of green travel behavior.

The design of items for household heterogeneity factors was mainly obtained from the China Statistical Yearbook and correlational researches of environmental behavior from international and 
national studies. The current situation of urban residents' travel modes was measured by census of urban residents' major transportation in daily travel. The items for green travel behavior were mainly designed and measured using scales from established international and national studies (Smith-Sebasto and D'Costa [14], Qu and Pan [50], Pan [51], Wang [52], and Yang [53]), the related information on the Chinese official website of green travel [54], and the official website of green travel foundation of China Association for NGO Cooperations [55]. To combine these data with the actual characteristics of Chinese urban residents' green travel behavior, the items were localized, amended, and redesigned. The green travel behavior section covered two areas: practice-based green travel behavior and promotion-based green travel behavior (totally covering six items). Of which, three examples of practice-based green travel behavior were presented, such as taking more public transport instead of driving or taking taxi. Similarly, three examples of promotion-based green travel behavior were presented, such as persuading the people around to take more public transport instead of driving or taking taxi. The answers were given on a five-point scale: rarely, sometimes, half the time, mostly, and very often. Using these examples, the green travel behavior characteristics of every respondent were determined.

\subsection{Data Sources}

Urban residents of the east China region (which included the following ten provinces or cities: Beijing, Tianjin, Hebei, Shanghai, Jiangsu, Zhejiang, Fujian, Shandong, Guangdong, and Hainan) were regarded as the subjects of this questionnaire survey. The questionnaires were distributed in a month-long field study from 10 November 2015 to 10 December 2015, and network research was also used. The Internet-based questionnaires were sent by online questionnaire survey platform, and by email using various methods with the assistance of schoolmates, colleagues, friends, and relatives. Finally, 1300 field questionnaires were issued, and 1082 field questionnaires and 614 network questionnaires were regained. According to the screening principle of no item-missed and no same value for eight items in succession [56], 901 valid field questionnaires and 574 valid network questionnaires were regained with an $86.97 \%$ effective rate and $77.06 \%$ recovery rate. The city distribution of questionnaire data is shown in Table 2.

Table 2. The city distribution of questionnaire data.

\begin{tabular}{ccc}
\hline Province/City & Valid Questionnaires & Proportion \\
\hline Beijing & 104 & $7.05 \%$ \\
Tianjin & 236 & $16.00 \%$ \\
Hebei & 96 & $6.51 \%$ \\
Shandong & 340 & $23.05 \%$ \\
Jiangsu & 314 & $21.29 \%$ \\
Shanghai & 89 & $6.03 \%$ \\
Zhejiang & 105 & $7.12 \%$ \\
Fujian & 69 & $4.68 \%$ \\
Guangdong & 65 & $4.41 \%$ \\
Hainan & 57 & $3.86 \%$ \\
Total & 1475 & $100.00 \%$ \\
\hline
\end{tabular}

\subsection{The Test of Reliability and Validity}

Cronbach's $\alpha$ coefficient of SPSS 22.0 was used in this article to test the reliability of the green travel behavior scale. The results showed that the scale design had high reliability because the Cronbach's $\alpha$ coefficient of the green travel behavior scale was 0.774 , and the Cronbach's $\alpha$ coefficient of each item was between 0.729 and 0.755 . The Cronbach's $\alpha$ coefficient was not improved after an item was deleted, and the overall correlation coefficient and the multiple correlation square coefficient of each item was over 0.3 . The validity of green travel behavior scale was tested by exploratory factor analysis and confirmatory factor analysis, successively. Before the exploratory factor analysis, Kaiser-Meyer-Olkin 
(KMO) and Bartlett test were conducted and the results showed that the KMO value was greater than 0.7 and the chi-square value of Bartlett test was larger and statistically significant, thus the scale was suited for factor analysis (Table 3).

Using the principal component analytical method and maximizing the deviations orthogonal rotation, and according to the retrieval standard that the eigenvalue is greater than 1, two common factors were extracted from green travel behavior and their total square deviation probability was $68.72 \%$, which was relatively high. At the same time, the load value of each index item on its own factor was greater than 0.5 and on other factors were less than 0.5 , this indicated that the green travel behavior scale in this article had a good convergent validity and discriminant validity. Next, confirmatory factor analysis was done by Lisrel 8.70, and the results showed that all goodness-of-fit indexes met the requirements of ideal values, and the factor loadings of the two potential factors of green travel behavior on its own index items all met the traditional requirement that the factor loading was greater than 0.4 ; that is, the dependent variable scale had a good construct validity.

Table 3. The test results of reliability and validity.

\begin{tabular}{ccccccc}
\hline & Variables & Items & $\begin{array}{c}\text { Cronbach's } \alpha \\
\text { Coefficient }\end{array}$ & $\begin{array}{c}\text { KMO } \\
\text { Value }\end{array}$ & $\begin{array}{c}\text { Bartlett } \\
\text { Test }\end{array}$ & Sig. \\
\hline \multirow{2}{*}{$\begin{array}{c}\text { Green travel } \\
\text { Behavior }\end{array}$} & $\begin{array}{c}\text { Practice-based green } \\
\text { travel behavior }\end{array}$ & 3 & 0.750 & & & \\
\cline { 2 - 5 } & $\begin{array}{c}\text { Promotion-based } \\
\text { green travel behavior }\end{array}$ & 3 & 0.778 & & 2973.060 & 0.000 \\
\hline
\end{tabular}

The results also showed that there was a correlation between the two common factors of green travel behavior, so a second order model was built to verify the existence of the high order, and also to verify the rationality of the classification mode of green travel behavior. As shown in Figure 1, compared with the first order model, the dependent variable second order model is more concise, and the factor loading of each first order factor is greater than 0.5 . This result indicates that the second order model of green travel behavior is rational, and the classification mode of green travel behavior is rational, in other words, green travel behavior can be well explained by practice-based green travel behavior and promotion-based green travel behavior.

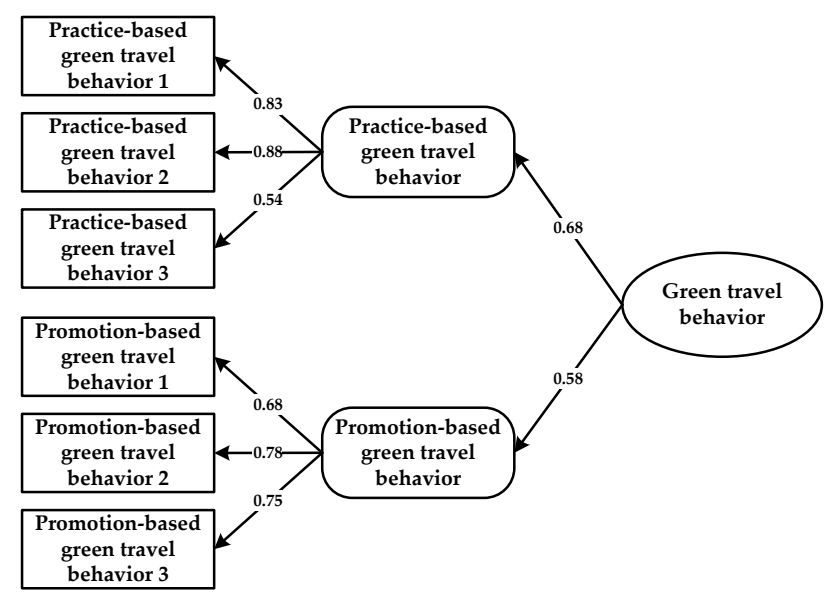

Figure 1. Path analysis of the second order model of the green travel behavior scale.

\section{Result Analysis and Discussion}

In this article, we used independent-samples $t$-test to analyze the difference in practice-based and promotion-based green travel behavior by gender, housing type, whether the family has elderly 
members over 60 -years old, and whether the family has children under 12 -years old. The results are shown in Table 4. In addition, we used one-way analysis of variance to compare practice-based with promotion-based green travel behavior by age, educational background, family monthly income, positional tiers, professional status, positional status, and the amount of private cars. The results are shown in Table 5.

Table 4. Variance analysis of green travel behavior on household heterogeneity factors based on independent-samples $t$-tests.

\begin{tabular}{|c|c|c|c|c|c|}
\hline \multirow{2}{*}{\multicolumn{2}{|c|}{ Variables and Attributes }} & \multicolumn{2}{|c|}{$\begin{array}{l}\text { Practice-Based Green } \\
\text { Travel Behavior }\end{array}$} & \multicolumn{2}{|c|}{$\begin{array}{c}\text { Promotion-Based Green } \\
\text { Travel Behavior }\end{array}$} \\
\hline & & c. $\cdots$ & Mean & & Mean \\
\hline Gender & $\begin{array}{c}\text { Male }(738,50.0 \%) \\
\text { Female }(737,50.0 \%)\end{array}$ & 0.000 & $\begin{array}{l}3.372 \\
3.637\end{array}$ & 0.005 & $\begin{array}{l}3.244 \\
3.389\end{array}$ \\
\hline Housing type & $\begin{array}{c}\text { Property owned } \\
(1100,74.6 \%) \\
\text { Property not owned } \\
(375,25.4 \%)\end{array}$ & 0.000 & $\begin{array}{l}3.387 \\
3.850\end{array}$ & 0.003 & $\begin{array}{l}3.272 \\
3.445\end{array}$ \\
\hline $\begin{array}{l}\text { Family members over } \\
60 \text {-years-old }\end{array}$ & $\begin{array}{l}\text { Yes }(575,39.0 \%) \\
\text { No }(900,61.0 \%)\end{array}$ & 0.000 & $\begin{array}{l}3.390 \\
3.577\end{array}$ & 0.067 & $\begin{array}{l}3.258 \\
3.354\end{array}$ \\
\hline $\begin{array}{l}\text { Family members } \\
\text { under 12-years-old }\end{array}$ & $\begin{array}{l}\text { Yes }(732,49.6 \%) \\
\text { No }(743,50.4 \%)\end{array}$ & 0.000 & $\begin{array}{l}3.244 \\
3.389\end{array}$ & 0.054 & $\begin{array}{l}3.267 \\
3.365\end{array}$ \\
\hline
\end{tabular}

Note: Mean value refers to the mean value of similar respondents' self-reports of their implementation situation of green travel behavior ( 1 = rarely, 2 = sometimes, $3=$ half the time, $4=$ mostly, $5=$ very often).

As shown in Table 4, practice-based and promotion-based green travel behaviors show significant variations by gender, which conforms to the theoretical assumption in this article. The comparative analysis results of average values show that the frequency of practice-based green travel behavior for females (3.637) is higher than for males (3.372), as well as promotion-based green travel behavior (females $3.389>$ males 3.244). This result is in accord with the conclusions of Golob and Hensher [21] and Prillwitz and Barr [22]. In terms of practice-based green travel behavior, as shown in Figure 2, the statistical results of urban residents' travel modes indicate that males prefer non-green travel modes such as private car and taxi, while females prefer green travel modes such as public transport, bicycle/electric bicycle, and walking. This statistical result is consistent with the result of Simma and Axhausen [23]. The reason could be that males pay more attention to efficiency, such as speed and comfort level, and females pay more attention to the cost and energy conservation in most cases [57]. In terms of promotion-based green travel behavior, compared to males, females are more willing to participate in green travel correlated activation and are willing to suggest or persuade others to implement green travel behavior. The reason may be that, in the Chinese context, females seem to engage in small group activities, such as shopping and chatting, more frequently than males, and it is easier to recommend joint activities with others in a small group [34].

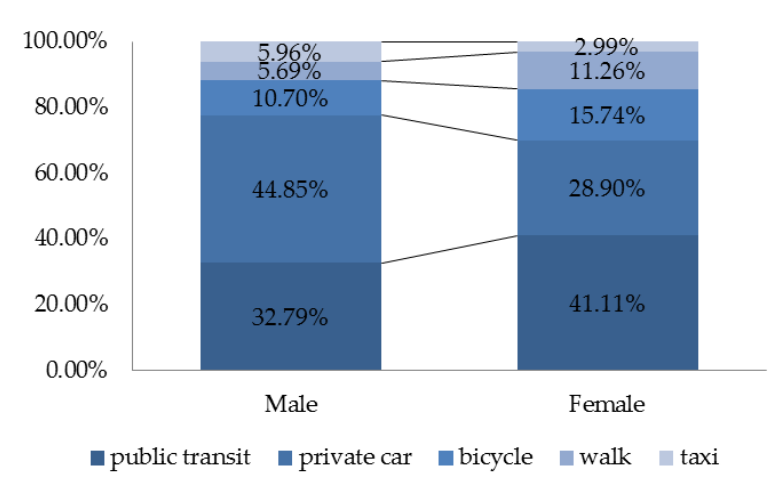

Figure 2. Proportions of different travel modes by gender. 
As shown in Table 4, practice-based and promotion-based green travel behaviors show significant variations by housing type, which conforms to the theoretical assumption in this article. The comparative analysis results of average values show that the frequency of practice-based green travel behavior of the group with house ownership (3.850) is higher than the group who do not have house ownership (3.387); similar results were obtained with promotion-based green travel behavior (house ownership $3.445>$ do not have house ownership 3.272). This result is in accord with the conclusions of Black et al. [36] and Painter et al. [37]. In terms of practice-based green travel behavior, as shown in Figure 3, the statistical results of urban residents' travel modes indicate that the proportions of green travel modes, such as public transit, cycling and walking, in the group who do not own their houses are apparently higher than the group who own their houses. The proportion who have private cars is apparently higher for those with house ownership than for those who do not. The reason for this may be that job and life stability and family economic strength of the house ownership group are higher than the group who do not have house ownership in most cases, as a consequence, the group who own their houses is more likely to own a private car [35]. In terms of promotion-based green travel behavior, compared to the group who do not own their houses, the group who have housing ownership is more willing to participate in green travel correlated activation and is willing to suggest or persuade others to implement the green travel behavior that they practice.

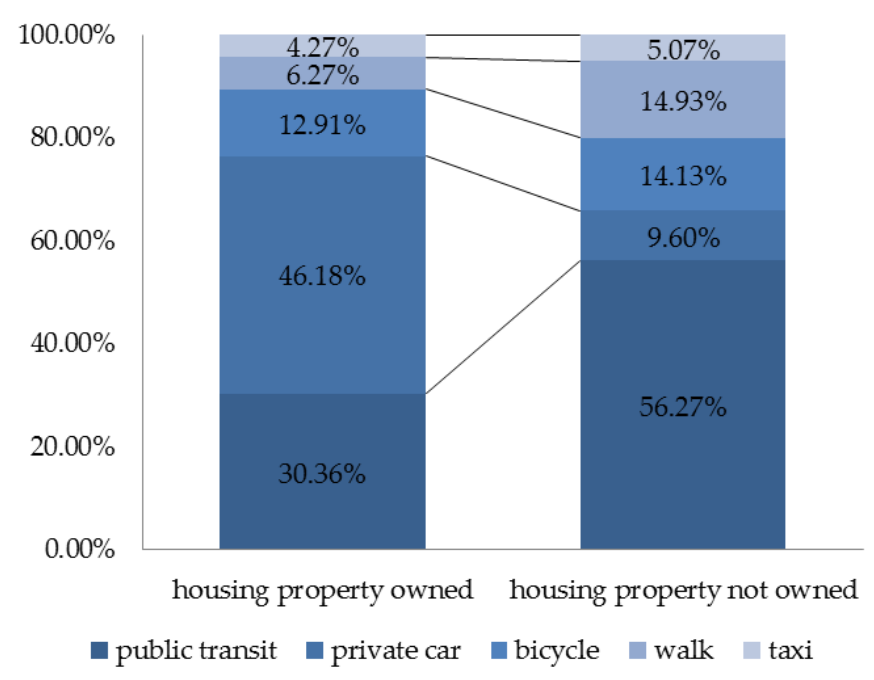

Figure 3. Proportions of different travel modes by house ownership.

As shown in Table 4, only practice-based green travel behavior shows significant variation when a family has elderly members or children, which partially conforms to the theoretical assumption in this article. The comparative analysis results of average values show that the frequency of practice-based green travel behavior of the group who do not have elderly family members or children $(3.577,3.389)$ is higher than the group who has elderly family members or children $(3.390,3.244)$. This result is in accord with the conclusions of Prillwitz and Barr [22] and Aydinalp et al. [38]. As shown in Figure 4, the statistical results of urban residents' travel modes indicate that the proportions of green travel modes such as public transit, cycling and walking in the group who do not have elderly family members or children are apparently higher than the group who do, while the proportion of private cars in the group who have elderly family members or children is apparently higher than the group who do not. Through our questionnaire survey, we knew that one of the reasons why many families buy private cars is to make travelling with the elderly or children easier. Perhaps this is the reason why the frequency of practice-based green travel behavior is relatively low for the families who have elderly members or children. 


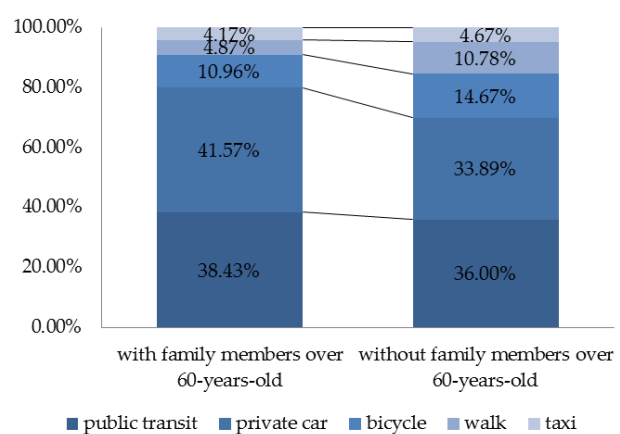

(a)

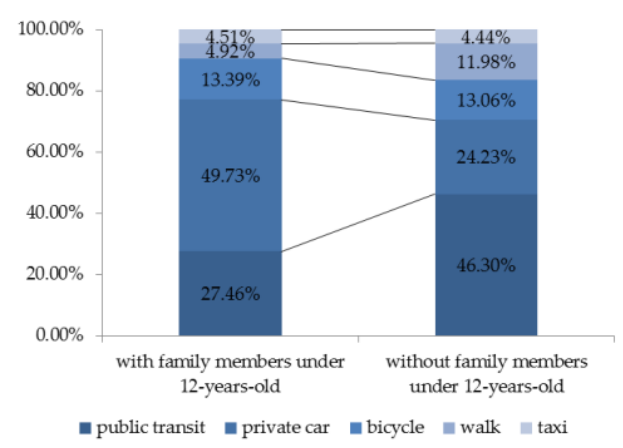

(b)

Figure 4. Proportions of different travel modes by family structure. (a) Denotes the family structure that whether there are elderly people over 60 years old in the family; (b) denotes the family structure that whether there are children under 12 years old in the family.

Table 5. Variance analysis of green travel behavior on household heterogeneity factors based on one-way analysis of variance.

\begin{tabular}{|c|c|c|c|c|c|}
\hline & \multirow{2}{*}{ Variables and Attributes } & \multicolumn{2}{|c|}{$\begin{array}{l}\text { Practice-Based Green } \\
\text { Travel Behavior }\end{array}$} & \multicolumn{2}{|c|}{$\begin{array}{c}\text { Promotion-Based Green } \\
\text { Travel Behavior }\end{array}$} \\
\hline & & Significance & $\begin{array}{l}\text { Mean } \\
\text { Value }\end{array}$ & Significance & $\begin{array}{l}\text { Mean } \\
\text { Value }\end{array}$ \\
\hline \multirow{5}{*}{ Age } & Under 18 years $(6,0.5 \%)$ & \multirow{5}{*}{0.000} & 4.111 & \multirow{5}{*}{0.017} & 3.222 \\
\hline & $18-30$ years $(797,54.0 \%)$ & & 3.690 & & 3.380 \\
\hline & $31-45$ years $(487,33.0 \%)$ & & 3.246 & & 3.220 \\
\hline & $46-60$ years $(160,10.8 \%)$ & & 3.281 & & 3.242 \\
\hline & Over 60 years $(25,1.7 \%)$ & & 3.920 & & 3.653 \\
\hline \multirow{5}{*}{$\begin{array}{l}\text { Educational } \\
\text { background }\end{array}$} & Junior high school or less $(45,3.1 \%)$ & \multirow{5}{*}{0.002} & 3.704 & \multirow{5}{*}{0.025} & 3.163 \\
\hline & Senior high school $(158,10.7 \%)$ & & 3.291 & & 3.095 \\
\hline & Junior college $(270,18.3 \%)$ & & 3.410 & & 3.312 \\
\hline & Bachelor $(732,49.6 \%)$ & & 3.528 & & 3.357 \\
\hline & Above bachelor $(270,18.3 \%)$ & & 3.627 & & 3.367 \\
\hline \multirow{7}{*}{$\begin{array}{c}\text { Family } \\
\text { monthly } \\
\text { income (Yuan) }\end{array}$} & Less than $4000(169,11.5 \%)$ & \multirow{7}{*}{0.000} & 3.953 & \multirow{7}{*}{0.000} & 3.548 \\
\hline & $4000-6000(335,22.7 \%)$ & & 3.695 & & 3.214 \\
\hline & $6000-8000(257,17.4 \%)$ & & 3.715 & & 3.463 \\
\hline & $8000-10,000(293,19.9 \%)$ & & 3.373 & & 3.358 \\
\hline & $10,000-30,000(322,21.8 \%)$ & & 3.215 & & 3.222 \\
\hline & $30,000-100,000(59,4.0 \%)$ & & 3.000 & & 3.209 \\
\hline & 100,000 or more $(40,2.7 \%)$ & & 2.700 & & 2.867 \\
\hline \multirow{4}{*}{$\begin{array}{l}\text { Amount of } \\
\text { private cars }\end{array}$} & $0(520,35.3 \%)$ & \multirow{4}{*}{0.000} & 3.969 & \multirow{4}{*}{0.013} & 3.414 \\
\hline & $1(736,49.9 \%)$ & & 3.342 & & 3.271 \\
\hline & $2(192,13.0 \%)$ & & 2.948 & & 3.276 \\
\hline & 3 or more $(27,1.8 \%)$ & & 2.938 & & 2.951 \\
\hline \multirow{5}{*}{$\begin{array}{l}\text { Positional } \\
\text { status }\end{array}$} & None $(1224,83.0 \%)$ & \multirow{5}{*}{0.003} & 3.550 & \multirow{5}{*}{0.152} & 3.324 \\
\hline & Family-level $(171,11.68 \%)$ & & 3.349 & & 3.207 \\
\hline & Department-level $(34,2.3 \%)$ & & 3.098 & & 2.971 \\
\hline & Stall or Bureau level $(18,1.2 \%)$ & & 3.074 & & 3.407 \\
\hline & Provincial or ministerial-level $(28,1.9 \%)$ & & 3.560 & & 3.429 \\
\hline \multirow{5}{*}{$\begin{array}{l}\text { Professional } \\
\text { status }\end{array}$} & None $(828,56.1 \%)$ & \multirow{5}{*}{0.000} & 3.586 & \multirow{5}{*}{0.003} & 3.296 \\
\hline & Primary $(244,16.5 \%)$ & & 3.526 & & 3.295 \\
\hline & Intermediate $(282,19.1 \%)$ & & 3.457 & & 3.482 \\
\hline & Sub-senior $(85,5.8 \%)$ & & 3.035 & & 3.020 \\
\hline & Senior $(36,2.4 \%)$ & & 2.963 & & 3.324 \\
\hline \multirow{5}{*}{ Positional tiers } & None $(299,20.3 \%)$ & \multirow{5}{*}{0.000} & 3.699 & \multirow{5}{*}{0.005} & 3.495 \\
\hline & Junior staff $(561,38.0 \%)$ & & 3.668 & & 3.282 \\
\hline & Front-line manager $(284,19.3 \%)$ & & 3.524 & & 3.324 \\
\hline & Middle manager $(253,17.2 \%)$ & & 3.225 & & 3.196 \\
\hline & Senior manager $(78,5.3 \%)$ & & 2.778 & & 3.239 \\
\hline
\end{tabular}

Note: Mean value refers to the mean value of similar respondents' self-reports of their implementation situation of green travel behavior ( $1=$ rarely, $2=$ sometimes, $3=$ half the time, $4=$ mostly, $5=$ very often). 
As shown in Table 5, practice-based and promotion-based green travel behaviors show significant variations by age, which conforms to the theoretical assumption in this article. The comparative analysis results of average values show that the frequency of green travel behavior of the middle-aged group (31-45 years and 46-60 years) is the lowest, and the youth and the elderly are relatively higher. This result is in accord with the conclusions of most scholars [25-29]. In terms of practice-based green travel behavior, as shown in Figure 5, the statistical results of urban residents' travel modes indicate that the middle-aged group prefers to choose private cars as their travel mode, and the reason may lie in their relatively stable social status and family incomes. The youth and the elderly prefer public transit, and the rate by which they choose private cars is relatively low. The reason may lie in their values, incomes, and travel attributes. In terms of promotion-based green travel behavior, the frequencies by youths under 30-years old and the elderly over 60-years old are relatively higher than the middle-aged group. The reason may be that, in the Chinese context, youths are more vigorous than the middle-aged group, and are more receptive to new things, and are more likely to participate in public activity, while the elderly are more frugal, and more likely to give others advice according to their experiences [34,58].

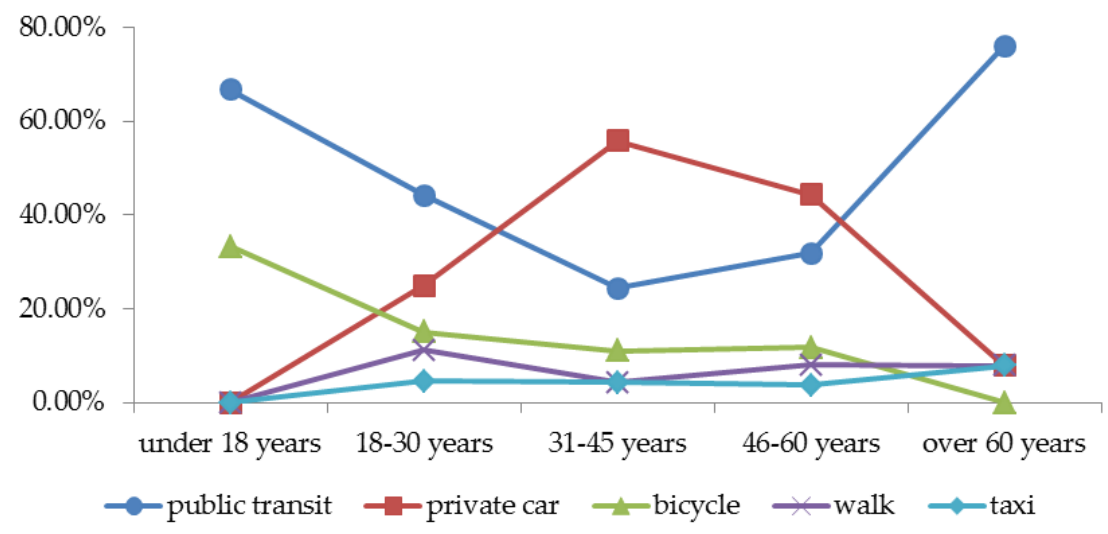

Figure 5. Proportions of different travel modes by age.

As shown in Table 5, practice-based and promotion-based green travel behaviors show significant variations by family monthly income, which conforms to the theoretical assumption in this article. The comparative analysis of average values shows that the frequency of urban residents' green travel behavior decreases with the level of family monthly income. This result is inconsistent with the research results of some developed countries [22,33], but is in accord with the research results of India [27] and China [29]. As shown in Figure 6, the statistical results of urban residents' travel modes indicate that the proportion of private car usage increases with the level of family monthly income, while the proportion using public transport and bicycles decreases with monthly income. The reason may be that, with the increase of income level, buying a private car will be affordable and a necessity for most families, especially young families.

As shown in Table 5, practice-based and promotion-based green travel behaviors show significant variations by educational background, which conforms to the theoretical assumption in this article. The comparative results of average values show that the frequency of urban residents' green travel behavior increases with their educational background level, except for junior high school or less. This result is in accord with the conclusions of Golob and Hensher [21] and Plaut [25]. The frequency of practice-based green travel behavior of the group with a junior high school degree or less is the highest, and that of promotion-based green travel behavior is also relatively higher than with other groups, and the reason may lie in the small sample size. As shown in Figure 7, the statistical results of urban residents' travel modes indicate that the relationship between the proportion of public transit and urban residents' educational background level is a " $\mathrm{U}$ "-shaped curve, and the proportion of public transit in the group with a junior college level is the lowest. While the relationship between proportion 
of private car and urban residents' educational background level is a "converse-U"-shaped curve, and the proportion of private cars in the group with junior college level is the highest. The reason may be that urban residents' behavior could be influenced by other factors, such as the urban residents' environmental awareness and income, while the environmental cognition and environment protection consciousness will increase with their educational background level, as well as their income. However, the influences of environmental awareness and income on green travel behavior are the opposite.

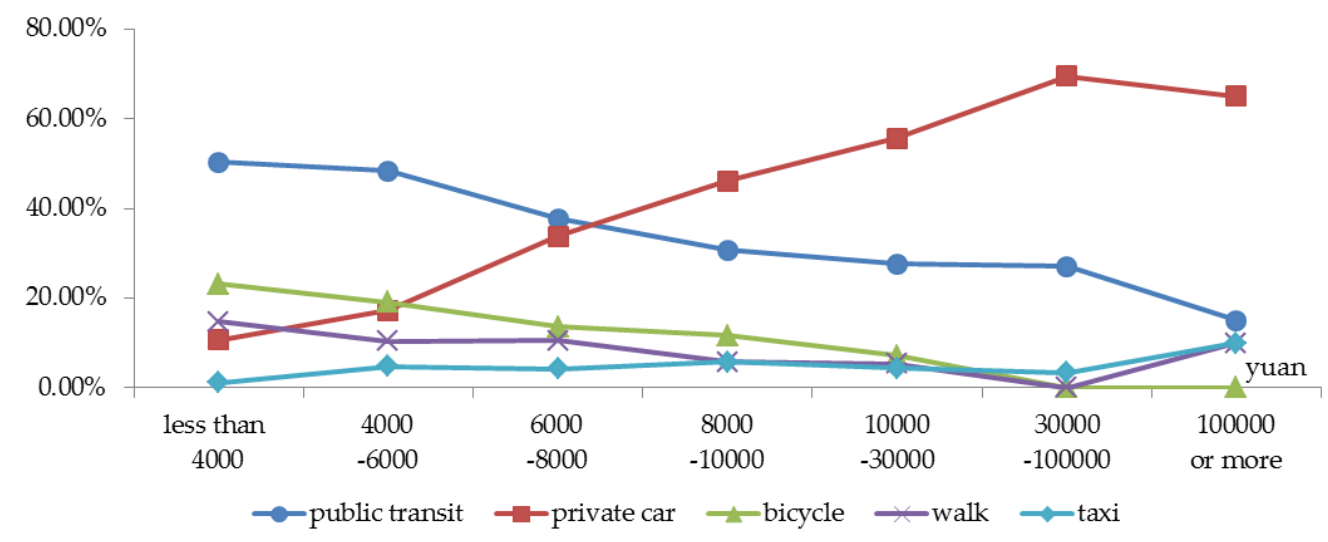

Figure 6. Proportions of different travel modes by family monthly income.

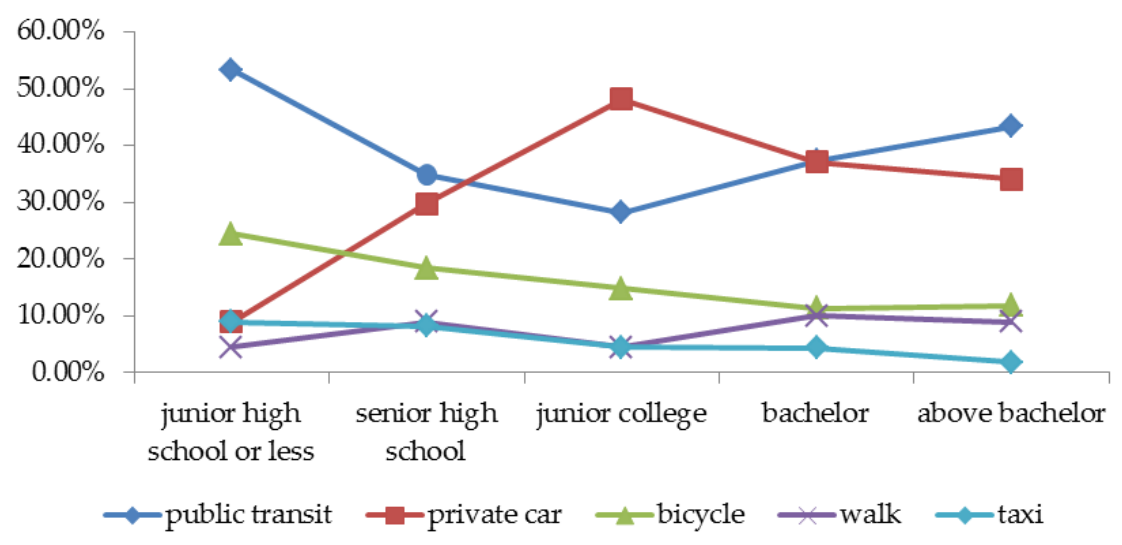

Figure 7. Proportions of different travel modes by educational background.

As shown in Table 5, practice-based and promotion-based green travel behaviors show significant variations by the amount of cars owned by the family, which conforms to the theoretical assumption in this article. The comparative analysis results of average values show that the frequency of urban residents' green travel behavior can decrease with the amount of cars owned by the family. This result is in accord with the conclusions of Golob and Hensher [21] and Plaut [25] and Susilo et al. [39]. As shown in Figure 8, the statistical results of urban residents' travel modes indicate that the proportion of private car usage increases with the amount of cars owned by the family, while the proportion of other travel modes decreases with the amount of cars owned by the family.

As shown in Table 5, practice-based and promotion-based green travel behaviors show significant variations by professional status and positional tiers, only practice-based green travel behavior shows significant variation by positional status, which partially conforms to the theoretical assumption in this article. The comparative analysis results of average values show that the frequency of urban residents' practice-based green travel behavior can decrease with their positional status, and the frequency of urban residents' practice-based and promotion-based green travel behavior can decrease with their professional status and positional tiers. This result is inconsistent with the conclusions of Liu [35] and Curtis [46]. As shown in Figure 9, the statistical results of urban residents' travel modes indicate 
that the proportion of private car usage increases with their positional status, professional status, and positional tiers, while the proportion of public transit, cycling and walking decreases with their positional status, professional status, and positional tiers. The reason may be that urban residents' income could increase with their positional status or professional status or positional tiers in most cases, while the rate of owning a private car also could increase with their income in most cases. It should be pointed out that some errors may exist in the above results because of the small sample size of the provincial and ministerial levels in the positional status and senior professional status.

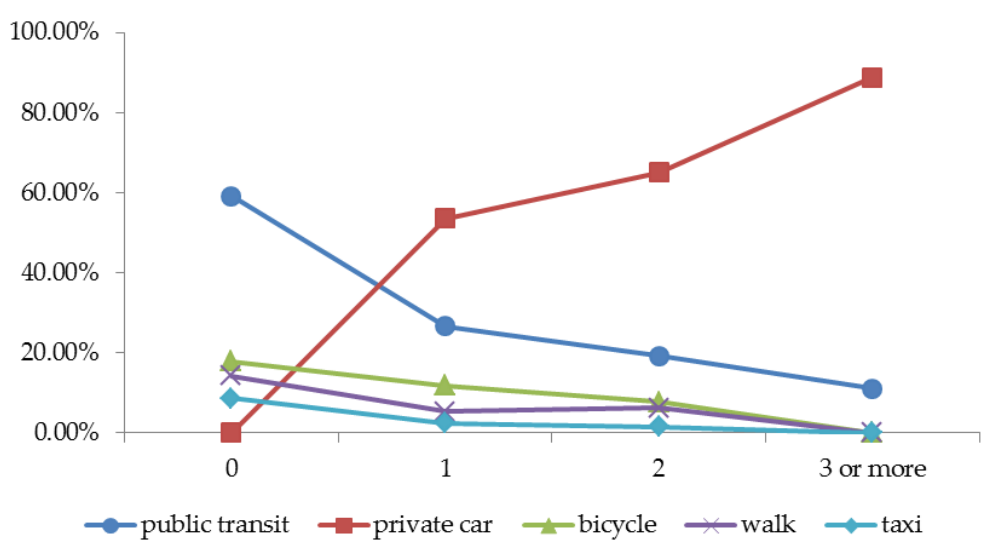

Figure 8. Proportions of different travel modes by the amount of private cars.

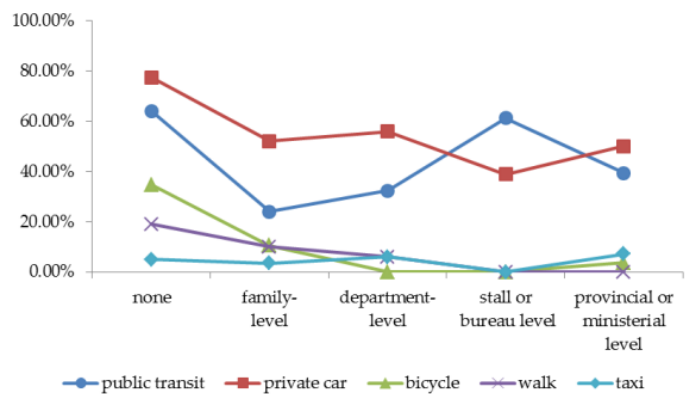

(a)

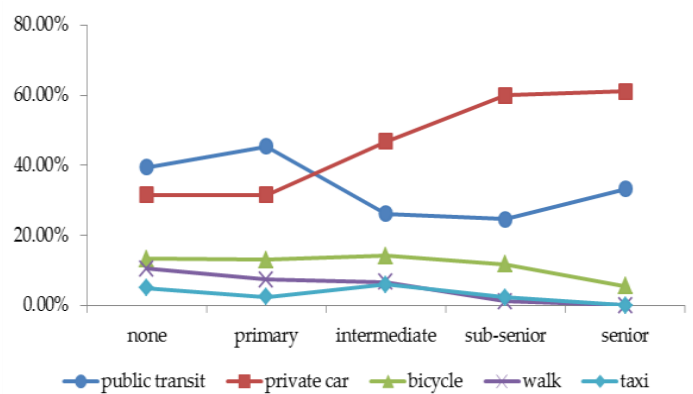

(b)

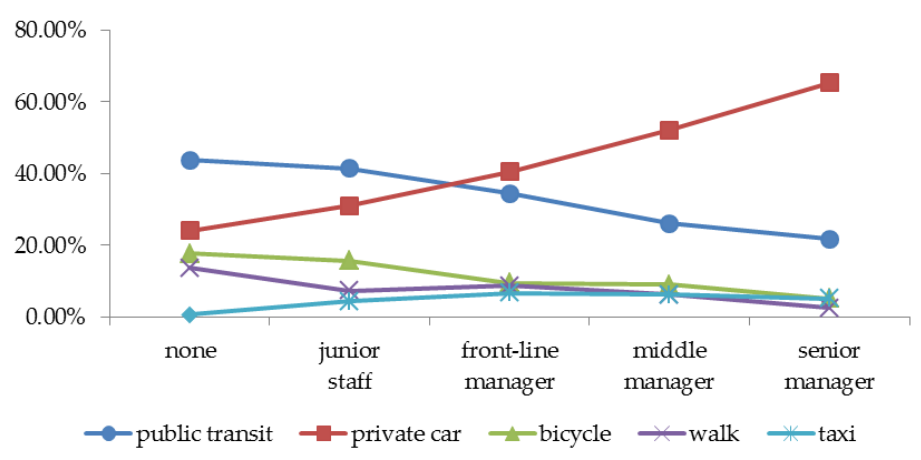

(c)

Figure 9. Proportions of different travel modes by positional status, professional status and positional tiers. (a) Denotes positional status; (b) denotes professional status; (c) denotes positional tiers.

\section{Conclusions and Policy Implications}

In conclusion, this study shows that both practice-based and promotion-based green travel behavior shows significant variation by household heterogeneity factors. In practical terms, females, the elderly and the young, highly educated, low income, low professional status, low positional 
tiers, low positional status, house-renting, no elderly family members or children, and having fewer cars has a significantly positive impact on green travel behavior. Therefore, according to the questionnaire survey statistical results, this article proposes the following policy changes to enhance public participation and initiative in green travel behavior.

(1) Pay attention to females, the young and the elderly, and attach importance to their strong characters and functions in formulation and implementation of green travel behavior guiding policies. In China, females are the main consumer of their family and the main educator of their children in most cases, so females could have a significant influence on the consumption views of their family and children. In most cases, the young are information-rich, are quick to accept new things, will positively participate in social activities, and are the main force of future family consumption. In China, respect and honor of the elderly is a traditional virtue, so the thoughts and behaviors of the elderly could have significant influence on the thoughts and behaviors of other family members. The results of this study indicate that the implementation frequency of females, the young and the elderly is relatively high. For this reason, and in order to make better use of guiding policies, relevant departments should pay attention to those groups as key breakthrough and target groups in the formulation and implementation of green travel behavior guiding policies.

(2) Pay attention to the positive impacts of educational background on green travel behavior. The results of this study indicate that there is a positive correlation between the frequency of green travel behavior and urban residents' educational background; in other words, the implementation frequency of urban residents' green travel behavior can increase with educational background. Therefore, relevant policymakers should take into account publicity channels and contents of green travel behavior in the process of receiving and implementing education in order to increase urban residents' environmental awareness.

(3) Guide urban residents' consumption views correctly, and cultivate and enhance urban residents' green travel cognition. In order to increase the comfort level of life, most urban residents will increase their consumption level with their income. One of those manifestations is buying one or more private cars, and the private car has become the second biggest demand of the family after housing. The results of this study indicate that there is a negative correlation between the implementation frequency of green travel behavior and urban residents' family income and the amount of private cars. To promote the development of green travel does not mean to limit urban residents' travel consumption but to guide urban residents to establish low carbon consumption in order to avoid excessive and luxury consumption.

(4) Emphasize guiding the house-renting group in order to accustom them to green travel behavior. In our samples, the house-ownership group accounts for 75 percent and the house-renting group accounts for 25 percent. Our statistical results show that the implementation rate of the house-renting group is significantly higher than that of the house-ownership group. In China, buying a house is a rigid demand of a family, and the present house-renting group may own their own property eventually. Perhaps the relatively high implementation rate of green travel behavior by the house-renting group may be limited by the family's current economic capabilities, but if the house-renting group could be actively guided by relevant policy makers, and their environmental protection awareness cultivated, their temporary green travel behavior is likely to be normalized and accustomed imperceptibly.

(5) Guide green travel behavior of the group who live with the elderly or children. It is a traditional virtue in China to respect the elderly and take good care of children, and one of the original intentions of buying private cars by many families is to make travel easier for the elderly or children. Our research results show that, as independent travelers, the implementation rate of the elderly is relatively high. However, as family members, the elderly or children can decrease the implementation rate of green travel behavior by the head of the household. Therefore, the relevant policy makers should guide green travel behavior of those groups who live with the elderly or children by utilizing incentive measures, and cultivate low-carbon awareness and low-carbon consumption patterns by increasing publicity channels and contents. 
We have observed a number of limitations in this study. Although our research samples involved urban residents of ten provinces or cities in the east China region, there is discrepancy in the quantities of research samples among different provinces or cities. Therefore, it is recommended that future research should enrich and extend the research samples to improve the universality of the research conclusion. Second, this study was based upon the urban residents' self-reports of their implementation situation of green travel behavior rather than upon field observations. Self-reports may produce social desirability bias, which could affect the authenticity of the results. Therefore, it is recommended that future research should use more survey methods to collect data, such as long-term field observations supplemented by interviews. However, despite these limitations, this explorative research has helped us to further the study of implementation situation and influencing factors of urban residents' green travel behavior.

Acknowledgments: We would like to thank the Natural Science Foundation of China (Grant Number: 71473247), and acknowledge the editors and reviewers for their language assistance and valuable comments.

Author Contributions: Ruyin Long came up with the original idea for this article. Ranran Yang led the research hypothesis design, the data collection and analysis. Ruyin Long and Ranran Yang designed the survey and wrote the article. Yu Bai and Lanlan Li led the manuscript check and modification. All authors read and approved this version.

Conflicts of Interest: The authors declare that they have no conflict of interest.

\section{References}

1. Niu, W.Y. Chinese New-Type Urbanization Report 2012; Science Press: Beijing, China, 2012. (In Chinese)

2. ChinaIRN.com. DiDi Published Chinese Urban Transportation Report of 2016 First Half Year. 2016. Available online: http:/ / www.chinairn.com/news/20160714/16425045.shtml (accessed on 14 July 2016). (In Chinese)

3. Li, X.; Zhang, G.H.; Huang, K.P. The green way to the development of Chinese urban transportation. Urban Plan. Forum 2008, 6, 51-56. (In Chinese)

4. People.com. What Is Green Travel? 2010. Available online: http://env.people.com.cn/GB/178688/180057/ 10798248.html (accessed on 19 January 2010). (In Chinese)

5. International Energy Agency (IEA). $\mathrm{CO}_{2}$ Emissions from Fuel Combustion Highlights. 2015. Available online: http://www.iea.org/publications/freepublications/publication/co2-emissions-fromfuel-combustion-highlights-2015.html (accessed on 24 March 2016).

6. Wang, Z.H.; Liu, W. The impacts of individual behavior on household daily travel carbon emissions in Beijing, China. Energy Procedia 2014, 61, 1318-1322. [CrossRef]

7. SOHU.com. Motor Vehicle Exhaust Emission Is Exceeding, and Is Hazardous for Human Health. 2015. Available online: http://mt.sohu.com/20151016/n423438354.shtml (accessed on 16 October 2015).

8. China State Statistics Bureau. China Statistical Yearbook. Available online: http://www.stats.gov.cn/tjsj/ ndsj/ (accessed on 24 January 2017). (In Chinese)

9. China Big Data Industrial Observation. AMAP Published Analysis Reports of Urban Traffic in Major Chinese Cities of 2015. 2016. Available online: http://www.cbdio.com/BigData/2016--01/21/content_4524265.htm (accessed on 21 January 2016). (In Chinese)

10. Atmospheric Environment Center of Yale-Nanjing University of Information Science \& Technology. Study of Chinese PM2.5 Spatial and Temporal Distribution. 2015. Available online: http://news.mydrivers.com/1/ 451/451740.htm (accessed on 15 October 2015). (In Chinese)

11. Hines, J.M.; Hungerford, H.R.; Tomera, A.N. Analysis and synthesis of research on responsible environmental behavior: A meta-analysis. J. Environ. Educ. 1986, 18, 1-8. [CrossRef]

12. Hsu, S.J.; Roth, R.E. An assessment of environmental literacy and analysis of predictors of responsible environmental behavior held by secondary teachers in the Hualien area of Taiwan. Environ. Educ. Res. 1998, 4, 229-249. [CrossRef]

13. Sia, A.P.; Hungerford, H.R.; Tomera, A.N. Selected predictors of responsible environmental behavior: An analysis. J. Environ. Educ. 1986, 17, 31-40. [CrossRef]

14. Smith-Sebasto, N.J.; D'Costa, A. Designing a likert-type scale to predict environmentally responsible behavior in undergraduate students: A multistep process. J. Environ. Educ. 1995, 27, 14-21. [CrossRef] 
15. Stern, P.C. Toward a coherent theory of environmentally significant behavior. J. Soc. Issues 2000, 56, 407-424. [CrossRef]

16. Gatersleben, B.; Steg, L.; Vlek, C. Measurement and determinants of environmentally significant consumer behavior. Environ. Behav. 2002, 34, 335-362. [CrossRef]

17. Brounen, D.; Kok, N.; Quigley, J.M. Energy literacy, awareness, and conservation behavior of residential households. Energy Econ. 2013, 38, 42-50. [CrossRef]

18. Han, Q.; Nieuwenhijsen, I.; Vries, B.; Blokhuis, E.; Schaefer, W. Intervention strategy to stimulate energy-saving behavior of local residents. Energy Policy 2013, 52, 706-715. [CrossRef]

19. Huang, S.S.; Song, R.; Tao, Y. Behavior of urban residents travel mode choosing and influencing factors-Taking Beijing as an example. Commun. Stand. 2008, 9, 24-128. (In Chinese)

20. Xu, F.; Xiao, Q.; Xu, G.H. Factor analysis of urban residents' green travel modes choice based on SPSS. China Collectiv. Econ. 2011, 7, 104-105. (In Chinese)

21. Golob, T.F.; Hensher, D.A. Greenhouse gas emissions and Australian commuters' attitudes and behaviour concerning abatement policies and personal involvement. Transp. Res. D Transp. Environ. 1998, 3, 1-18. [CrossRef]

22. Prillwitz, J.; Barr, S. Moving towards sustainability? Mobility styles, attitudes and individual travel behavior. J. Transp. Geogr. 2011, 19, 1590-1600. [CrossRef]

23. Simma, A.; Axhausen, K.W. Structures of commitment in mode use: A comparison of Switzerland, Germany and Great Britain. Transp. Policy 2001, 8, 279-288. [CrossRef]

24. Polk, M. The influence of gender on daily car use and on willingness to reduce car use in Sweden. J. Transp. Geogr. 2004, 12, 185-195. [CrossRef]

25. Plaut, P.O. Non-motorized commuting in the US. Transp. Res. D Transp. Environ. 2005, 10, 347-356. [CrossRef]

26. Klineberg, S.L.; McKeever, M.; Rothenbach, B. Demographic predictors of environmental concern: It does make a difference how it's measured. Soc. Sci. Q. 1998, 79, 734-753.

27. Singh, N. Exploring socially responsible behavior of Indian consumers: An empirical investigation. Soc. Responsib. J. 2009, 5, 200-211. [CrossRef]

28. Liu, Q. Sustainable Consumption Which Support the Development of Low-Carbon Economy; Economic Science Press: Beijing, China, 2010. (In Chinese)

29. Wang, J.M. Empirical study on urban residents' resource-efficient consumption behavior. Economist 2007, 1, 38-44. (In Chinese)

30. Ma, J.H.; Liao, N. Investigation of urban residents' low-carbon travel in Xi'an. New West 2015, 16, 19. (In Chinese)

31. Böhler, S.; Grischkat, S.; Haustein, S.; Hunecke, M. Encouraging environmentally sustainable holiday travel. Transp. Res. A 2006, 40, 652-670. [CrossRef]

32. Jackson, D.T. Household energy consumption in the UK: A highly geographically and socio-economically disaggregated model. Energy Policy 2008, 36, 3167-3182.

33. Franzen, A.; Meyer, R. Environmental attitudes in cross-national perspective: A multilevel analysis of the ISSP 1993 and 2000. Eur. Sociol. Rev. 2010, 26, 219-234. [CrossRef]

34. Yue, T. Study on Influencing Factors and Guiding Policies of Urban Residents' Energy-Saving Behavior. Ph.D. Thesis, China University of Mining and Technology, Xuzhou, China, 2014. (In Chinese)

35. Liu, J.X.; Yan, H.W.; Liu, G.Y. Investigation of community residents' green consuming behavior and related message propagation. J. Taiwan Health Educ. 2000, 13, 189-212.

36. Black, J.S.; Sterm, P.; Elworth, J.T. Personal and contextual influences on household energy adaptions. J. Appl. Psychol. 1985, 70, 3-21. [CrossRef]

37. Painter, J.; Semenik, R.; Belk, R. Is there a generalized conservation ethic? A comparison of the determinants of gasoline and home heating energy conservation. J. Econ. Psychol. 1983, 3, 317-331. [CrossRef]

38. Aydinalp, M.; Ugursal, V.I.; Fung, A.S. Modeling of the appliance, lighting, and space-cooling energy consumptions in the residential sector using neural networks. Appl. Energy 2002, 71, 87-110. [CrossRef]

39. Susilo, Y.O.; Williams, K.; Lindsay, M.; Dair, C. The influence of individuals' environmental attitudes and urban design features on their travel patterns in sustainable neighborhoods in the UK. Transp. Res. D Transp. Environ. 2012, 17, 190-200. [CrossRef]

40. Vining, J.; Ebreo, A. What makes a recycler? A comparison of recyclers and non-recyclers. Environ. Behav. 1990, 22, 55-73. [CrossRef] 
41. Schultz, P.W.; Oskamp, S.; Mainieri, T. Who recycles and when: A review of personal and situational factors. J. Environ. Psychol. 1995, 15, 105-121. [CrossRef]

42. Marcinkowski, T.J. An Analysis of Correlates and Predictors of Responsible Environmental Behavior. Ph.D. Thesis, Southern Lllionois University, Carbondale, IL, USA, 1988.

43. Scheiner, J. Does individualisation of travel behaviour exist? Determination of travel participation and mode choice in West Germany, 1976-2002. Die Erde 2006, 137, 355-377.

44. Hjorthol, R. Daily mobility of men and women-A barometer of gender equality? In Gendered Mobilities; Uteng, T.P., Cresswell, T., Eds.; Ashgate: Aldershot, UK, 2008; pp. 193-210.

45. Samdahl, D.M.; Robertson, R. Social determinants of environmental concern: Specification and test of the model. Environ. Behav. 1989, 21, 57-81. [CrossRef]

46. Curtis, F.; Simpson-Housley, P.; Drever, S. Household energy conservation. Energy Policy 1984, 12, 452-456. [CrossRef]

47. Wang, J.M.; Wang, J.H. The influencing elements of the public low-carbon consumption, and the governments' regulatory policies. Manag. World 2011, 4, 58-68. (In Chinese)

48. Sun, Y. Study on the influence of household heterogeneity factors on the energy use behavior of urban residents. J. Beijing Inst. Technol. (Soc. Sci. Ed.) 2013, 15, 23-28. (In Chinese)

49. Gao, X.L.; Hou, C.Z. Review of family functional theories. Sci. Soc. Psychol. 2008, 23, 29-33. (In Chinese)

50. Qu, Y.; Pan, J.Y. Empirical analysis of influencing factors of China urban residents' green travel behavior. Liaoning Urban Rural Environ. Sci. Technol. 2014, 6, 62-66. (In Chinese)

51. Pan, J.Y. Influencing Factors of Residents' Green Travel Behavior in Large-Medium Cities. Master's Thesis, Dalian University of Technology, Dalian, China, 2014. (In Chinese)

52. Wang, Y.Q. Analysis of Crows Characteristics and Behavior Change Countermeasure of Urban Residents' Green Travel. Master's Thesis, Dalian University of Technology, Dalian, China, 2014. (In Chinese)

53. Yang, R.R.; Long, R.Y. Affecting factors of theoretical model in urban residents' green travel behavior: Based on grounded theory. Wuhan Univ. J. (Philos. Soc. Sci.) 2014, 67, 13-19. (In Chinese)

54. Green Travel. Available online: http://www.china.com.cn/chinese/zhuanti/lscx/1220797.htm (accessed on 24 January 2017).

55. Green Commuting. Available online: http://www.cleanair.net.cn/ (accessed on 24 January 2017).

56. Sun, Y. Study on Residents' Environmental Behavior and Its Influencing Factors. Ph.D. Thesis, Dalian University of Technology, Dalian, China, 2006. (In Chinese)

57. Schahn, J.; Holzer, E. Studies of individual environmental concern: The role of knowledge, Gender, and background variables. Environ. Behav. 1990, 22, 767-786. [CrossRef]

58. Yang, R.R.; Long, R.Y. Analysis of the influencing factors of the public willingness to participate in public bicycle projects and intervention strategies-A case study of Jiangsu Province, China. Sustainability 2016, 8 , 349. [CrossRef]

(C) 2017 by the authors; licensee MDPI, Basel, Switzerland. This article is an open access article distributed under the terms and conditions of the Creative Commons Attribution (CC BY) license (http:/ / creativecommons.org/licenses/by/4.0/). 